\title{
Tax Saving Investment Strategies among Salaried Individuals in Aurangabad City
}

\author{
Siddhaarth Dhongde, Vilas Epper
}

\begin{abstract}
This is too difficult for a mathematician. It takes a philosopher. The hardest thing in the world to understand is the income tax." -Albert Einstein Tax Management. Tax Management is an activity conducted by the tax payer to reduce the tax liability and maximize the use of all available deductions, allowances, exclusions, as per income tax act 1961. It is a techniques to prepare strategy of financial planning for longer term goal. In this paper analyzing investment products for tax saving purpose. The objective behind this research paper is to understand tax saving investment Management strategies among salaried induvial. On the same point view this research is an attempt to understand investment preference pattern and tax saving investment patterns among salaried individuals. Study outcomes reveals that the foremost adopted combination of tax saving instrument are PPF (Public Provident Fund), which got the primary rank during this study and therefore the other are Children education, LIC, Home Loan, NPS and other priority gives to Medical Insurance, National saving certificates, Fixed Deposits and ELSS.
\end{abstract}

Key Words: Investment Avenues, Income Tax, Tax Management, Financial Planning, Investment goals.

\section{INTRODUCTIONS}

Investment is the employment of funds with the aim of achieving additional income or growth in value. The essential quality of an investment is that it involves 'waiting' for a reward. It involves the commitment of resources which have been saved or put away from current consumption in the hope that some benefits will accrue in future. If the amount so saved is being invested, with a view to earn a good return, then the saving becomes investment and the saver becomes investor an individual has choice of various investment avenues where person's savings could be invested. The Choice of investment is based on degree risk and expected rate of return. Normally high returns may involve high risks and low returns accompanying low risk. Investment is always based on future goal and accordingly every induvial plan their investments. In terms of personal finance, saving refers to preserving money for future use typically by putting it on deposit - this is distinct from investment where there is an element of risk.(Yogesh $\mathrm{P}$ Patel \& Charul Y Patel, 2012). Any investment decision is a tradeoff between the risk and return.

Revised Manuscript Received on June 13, 2020.

* Correspondence Author

Prof. Siddhaarth R. Dhongde*, Associate Professor, Amity business School Mumbai, Amity University, Maharashtra, India.

Dr. Vilas Epper, Senior Professor, Dr. Babasaheb ambedkar university Auranganad.

(C) The Authors. Published by Blue Eyes Intelligence Engineering and Sciences Publication (BEIESP). This is an open access article under the CC BY-NC-ND license (http://creativecommons.org/licenses/by-nc-nd/4.0/)
In between the risk and return, investors' decision relating to investment depending on so many factors like higher return, safety, tax benefit, appreciation, Inflation, Risk cover, liquidity, regular income, Expert advice, past experience etc. It is important to plan one's finances and taxes properly. Plans should never be made on an ad-hoc basis or for a brief goal or towards an impractical objective. By proper tax planning, one not only reduces the liabilities but also find saving towards the varied goals one has set at different life stages. Salaried Individuals are more concern of tax planning, saving and Interment for short term as well as long-term. The planning is that the arrangement of one's financial affairs in such manner that without violating in any way the legal provisions, full advantage is taken to tax exemptions, deductions, concessions, rebates, allowances and other reliefs or benefits permitted under the tax Act." Effective tax planning requires one to loan one's income and affairs even before actually earnings the income. It's better to plan before than latter. A salaried person should bear in mind of the income- tax laws because it associated with income, the deduction and reliefs that are available. Tax planning has three main objectives - reduction of liabilities, minimum litigation and maximum contribution to your productive investments. It's important to know that the objectives of tax planning don't go against the thought of tax laws. Tax planning has two parts: a) Reducing your tax liability on the different types of income earned by you such as salary, interest and so on.b) Reducing your tax liability by investing in tax saving instruments which directly reduces the tax payable on your income. Salaried Employee while taking investment decision has main concern to save tax on income earned inform of salary and income from investing activities but most of make investments which are not suitable for meeting our overall financial goals. To avail complete the deduction section 80C i.e. maximum limit of Rs 1.5 lakh, most people usually buy an insurance policy without checking the policy is suitable for them e.g., if the sum insured offered is enough to cover their liabilities. This research paper is an attempt to understand and analyze salaried individual's interment pattern towards to save tax and to evaluate the combination of investment instruments.

\section{REVIEW OF LITERATURE}

(Suryanarayanan \& Seethalekshmy, 2017)in this research paper researcher analyses investment preferences among teachers working in junior colleges in the city of Mumbai. Selected financial products are taken for the purpose of the study. This research finds awareness of financial products, factors influencing decisions for investment and there investment preferences foe financial goal.
Blue Eyes Intelligence Engineering \& Sciences Publication (C) Copyright: All rights reserved.

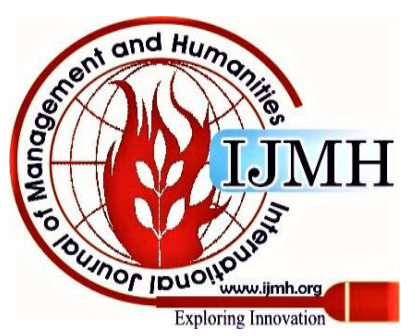




\section{Tax Saving Investment Strategies among Salaried Individuals in Aurangabad City}

Finally research paper revels that investors have low level of awareness and while taking investment decisions they preferred traditional avenues. It also highlights that investors take decisions with help from financial expert and family influence. (FCA Pratibha, 2012) the paper states that financial planning is very important plus play vital role setting investment goals. This research paper emphasis on designing effective portfolio management for better financial planning. Study explores association of demographic characteristics with the investment preferences of the individual investors. The main results of research are that fixed deposit is most preferred and capital market debt instruments are least preferred. Demographic variables have found to have significant association to investment preferences.

(Gautam, 2013) Tax planning is an essential part of our financial planning. Efficient tax planning enables us to reduce our tax liability to the minimum. He emphasizes that tax planning is investment model for specific purpose of individual's goal. Purpose of study was to find out the most suitable and popular tax saving instrument used to save tax and researcher examine that the amount saved by using that instrument. His findings revels that the most adopted tax saving instrument is Life Insurance policy, and the second most adopted tax saving instrument is Provident Fund.

(R Vasanthi, 2015) in this research paper research explain the importance of tax planning and how it has played vital role in economic development of country. Scholar suggested in his work that sex (Male.Female) have influence over the amount of tax paid, whereas the age of respondents has low influence over the amount of tax paid. It also evident from the study that experienced employees are willing to pay tax because of several personal factors. Further, the level of awareness of the respondents is significantly higher over the different tax savings scheme.

(Arora \& Garg, 2019) in this research is an attempt to know the awareness and perception regarding various tax saving instruments available to save the tax to the teachers of higher education. The teachers are well aware of the various deductions, reliefs, and rebates available as per the Indian income tax act. They prefer those options of investment which are having low risk, high returns, and full tax benefits.

(Saravanan \& MuthuLakshmi, 2017) according to research most suitable and popular tax saving instrument used to save tax and also to examine the amount saved by using that instrument. Over all findings reveals that the most adopted tax saving instrument is Provident Fund, which got the first rank in this study and the second most adopted tax saving instrument is Life Insurance policy.

(ARORA, *MONIKA (Research Scholar, 2019) research paper is related with sensitive and personal financial aspects of individual income tax assessees. the researcher to undertake an empirical research on the topic to identify the factors that influence the individual assessees to invest in tax-saving schemes and scope for further investment. Depending upon their risk appetite, an increase has been witnessed in number of investment avenues available for investors.

\section{Objective}

$>$ To study the pattern of tax Management by Salaried individual.

$>$ To find out Tax saving strategies adopted by salaried individuals

$>$ To make appropriate suggestion and conclusion.

\section{Limitation}

- $\quad$ The study shall be conducted limited to salaried individual.

- $\quad$ The study is limited to Aurangabad

\section{Hypotheses}

- $\quad$ Hypotheses 1

Ho: There is no significant influencing factors among salaried individuals in assigning ranks to factors.

$\mathrm{H1}$ : There is significant influencing factors among salaried individuals in assigning ranks to factors

- $\quad$ Hypotheses 2

Ho: There is no significant association between age and preferred tax deductions claim under 80C other

$\mathrm{H} 1$ : There is a significant association between age and preferred tax deductions claim under $80 \mathrm{C}$ and other

- Hypotheses 3

- Ho: There is no significant differences exists in tax saving investment products combinations in salaries induvial

- H1: There is a significant differences exists in tax saving investment products combinations salaries induvial

\section{RESEARCH METHODOLOGY}

The present study is based on primary data collected from salaried individual income tax assesse from Aurangabad city. Secondary data from collected from various source such as articles, Journals, Magazine and experiences. This research work is examine to salaried assesee only. The primary data is collected through mails and direct interviews through mobile or face to face. The study target 600 salaried individuals working in Aurangabad city based on convenience sampling method. Out of 600 targeted respondent received 512 responses. The Survey was conducted in the month of January and February 2020. The sample size was measured by using the ungrouped one stage probability sampling from random selection.

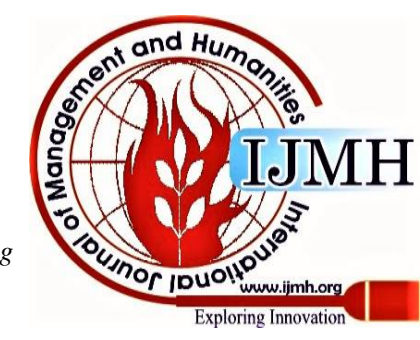




\section{DATA ANALYSIS}

INVESTMENT PATTERN OF THE SALARIED INDIVIDUALS

Everybody needs to put their cash in a legitimate speculation channel. Be that as it may, the speculation decision is the contrast from speculator to a financial specialist. Presently a-days, numerous venture choices are made accessible to improve the speculation conduct of the financial specialists. Every speculation elective has its own benefits and negative marks. Despite the fact that, all the speculators are extremely mindful while putting their cash in different venture roads. Henceforth, it is decided to examine the investment pattern of the sample salaried Individuals. For analysis purpose, investment channel of the sample salaried Individuals are classified into eleven viz., investment in immovable properties, bank deposits, NPS, life insurance corporation, provident fund, pension schemes, gold, silver and other precious metals, securities, National Savings Certificate (NSC), Medical Insurance, ELSS. The Table 1 exhibits the distribution of the salaried Individuals on the basis of their investment pattern.

\section{INVESTMENT PATTERN OF THE SALARIED INDIVIDUALS}

\begin{tabular}{|c|l|c|c|}
\hline $\begin{array}{c}\text { Sl. } \\
\text { No } \\
.\end{array}$ & Investment Avenues & $\begin{array}{l}\text { No. of } \\
\text { Salaried } \\
\text { Individuals }\end{array}$ & $\begin{array}{c}\text { Percentag } \\
\text { e in Total }\end{array}$ \\
\hline 1 & $\begin{array}{l}\text { Immovable } \\
\text { Properties }\end{array}$ & 28 & $25 \%$ \\
\hline 2 & Bank Deposits & 50 & $45 \%$ \\
\hline 3 & $\begin{array}{l}\text { Life Insurance } \\
\text { Corporation }\end{array}$ & 110 & $100 \%$ \\
\hline 4 & Provident Fund & 110 & $100 \%$ \\
\hline 5 & Pension Schemes & 88 & $80 \%$ \\
\hline 6 & $\begin{array}{l}\text { Oold, Silver and } \\
\text { Metals }\end{array}$ & 44 & $37 \%$ \\
\hline 7 & Securities & 22 & $15 \%$ \\
\hline 8 & NSC & 28 & $20 \%$ \\
\hline 9 & Medical Insurance & 24 & $14 \%$ \\
\hline 10 & ELSS & 13 & $12 \%$ \\
\hline
\end{tabular}

Table 1 reveals that all the sample salaried individual are choosing to insurance policy in Life Insurance Corporation of India and invested in Provident Fund, National Pension scheme and $45 \%$ of the sample salaried individual are invested in Bank deposits and in precious metal 37\%.

\section{INFLUENCING FACTORS OF SALARIED INDIVIDUALS FOR INVESTMENT AND FINANCIAL PLANNING}

Investment decision is a tradeoff between the risk and return. In between the risk and return, investors' decision relating to investment depending on so many factors like higher return, tax benefit, appreciation, liquidity, regular

Published By:

Blue Eyes Intelligence Engineering \& Sciences Publication income etc. the following table no.2 shows salaried individuals factors influencing investment decision

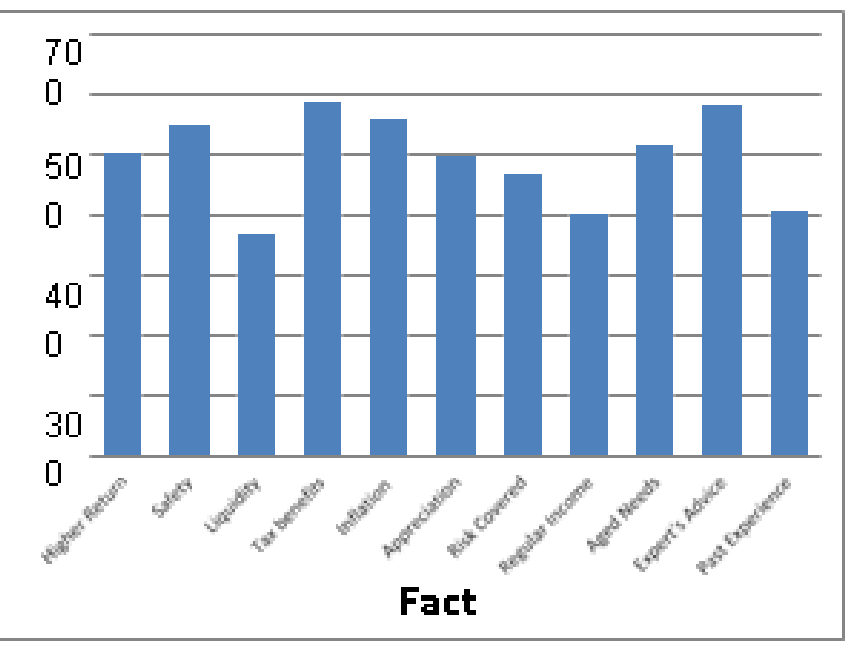

Table No 2.

Hypothesis Testing

Ho: There is no significant influencing factors among salaried individuals in assigning ranks to factors.

INFLUENCING FACTORS OF SALARIED INDIVIDUALS FOR INVESTMENT AND FINANCIAL PLANNING DECISION: KENDALL'S CO-EFFICIENT OF CONCORDANCE ('W')

Additional, to identify the factors influencing the salaried individuals for their investment decision, it is decided to use Kendall's Co-efficient of Concordance. Kendall's Co-efficient of Concordance also known as Kendall's ' $W$ '.It is a non-parametric statistic. It indicates the degree of association of ordinal assessments made by multiple appraisers when assessing the same samples which determines association between variables and measure of agreement among the raters or respondents. So with help of Kendall's Co-efficient of Concordance has been applied to find whether there is any similarity among the salaried Individuals in assigning the ranks to the given factors. Kendall's ' $W$ ' ranges from 0 (No agreement) to 1 (Complete agreement). Higher the value of Kendall's 'W' more will be the similarity among the salaried Individuals in assigning the ranks whereas, lower the value of Kendall's W less will be the similarity among the salaried Individuals in assigning the ranks. Mean scores have been calculated for the factors influencing the investment decision of salaried Individuals Lower mean score shows higher performance of the respective item. Details of the findings are shown in Table 3. 
Tax Saving Investment Strategies among Salaried Individuals in Aurangabad City

Table No.3 INFLUENCING FACTORS OF SALARIED INDIVIDUALS FOR INVESTMENT AND FINANCIAL PLANNING DECISION: KENDALL'S CO-EFFICIENT OF CONCORDANCE ('W')

\begin{tabular}{|c|c|c|c|c|}
\hline $\begin{array}{c}\text { Fact } \\
\text { ors }\end{array}$ & $\begin{array}{l}\text { Total } \\
\text { Score }\end{array}$ & $\begin{array}{l}\text { Mean } \\
\text { Score }\end{array}$ & $\begin{array}{l}\mathbf{R} \\
\mathbf{a} \\
\mathbf{n} \\
\mathbf{k}\end{array}$ & $\begin{array}{c}\text { Kendall' } \\
\mathbf{s} \text { ' } W \text { ' }\end{array}$ \\
\hline Higher return & 2981 & 5.82 & 6 & \\
\hline Safety & 2624 & 5.12 & 4 & \\
\hline Liquidity & 4216 & 8.23 & $\begin{array}{l}1 \\
1\end{array}$ & \\
\hline Tax benefit & 2228 & 4.35 & 1 & 0 \\
\hline Inflation & 2392 & 4.67 & 3 & 0 \\
\hline Appreciation & 3052 & 5.96 & 7 & 1 \\
\hline Risk covered & 3362 & 6.57 & 8 & \\
\hline Regular income & 3873 & 7.56 & $\begin{array}{l}1 \\
0\end{array}$ & \\
\hline Aged needs & 2954 & 5.77 & 5 & \\
\hline Expert's advice & 2267 & 4.43 & 2 & \\
\hline Past experience & 3843 & 7.51 & 9 & \\
\hline
\end{tabular}

Observation : In Table 3 reveals that the mean score for the factors influencing the salaried Individuals for their investment decision varies between the score of 4.35 to 8.23. The Kendall's ' $W$ ' is calculated for the above factors which is found to be 0.011 . It shows that there is less similarity among the salaried Individuals in assigning the ranks to the factors influencing the investment decision of salaried Individuals. Looking at the mean score, it is understood that the highest preference has been given to Tax benefit (lower the mean score and higher the priority) constituting the mean score 4.35 and the lowest preference is given to Liquidity. The moderate preference is given to Expert's advice, Inflation, Safety, Aged need, higher return, Appreciation, Risk covered, Past experience and Regular income. Hence it indicate that null hypothesis is accepted and it reveals that salaried individuals influencing factors of investment are similar and responses are unanimous.
Table No.4 AGE WISE PREFERRED TAX SAVING INVESTMENT PREFERENCE AND CLAIMS MADE UNDER SECTION 80C

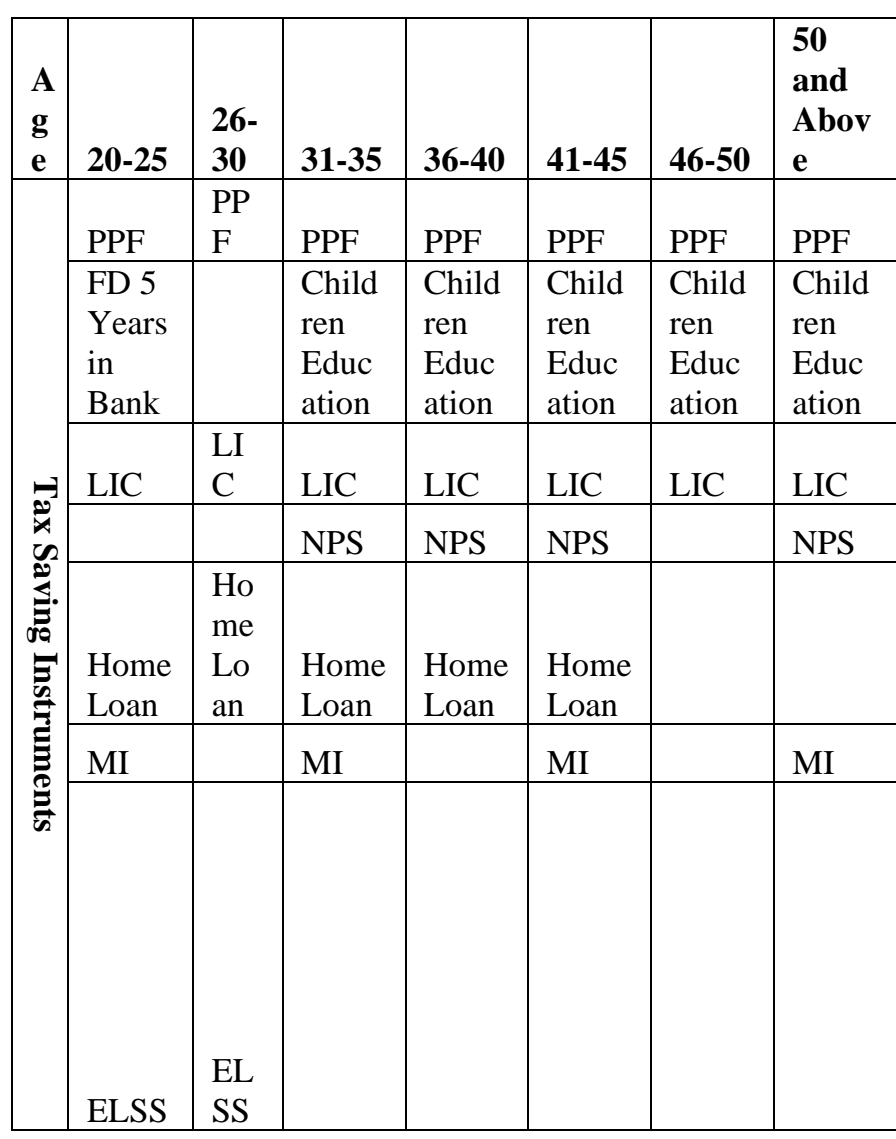

Age wise Preferred Tax saving Investment preference and Claims made under Section 80C shows that PPF \& LIC is the most common method used by salaried individuals for tax saving across all ages. In the case of, children education deduction preferred by all age except younger age bracket and it was the second most preferred means of claiming tax deductions under 80C. Another most chosen option among salaried individuals is Home loan across all age individuals are claiming. Lastly there is mix preference of Medical Insurance among all age.

\section{INVESTMENT PREFERENCES ANALYSIS OF SALARIED INDIVIDUALS FOR TAX SAVING}

Ho: There is no significant association between age and preferred tax deductions claim under $80 \mathrm{C}$ other

Wilcoxon Signed Ranks Test: The Wilcoxon signed-rank test is a non-parametric statistical hypothesis test used to compare two related samples, matched samples, or repeated measurements on a single sample to assess whether their population mean ranks differ (i.e. it is a paired difference test). Rank table shows the negative and positive rank score whether the pair has positive and negative scores.

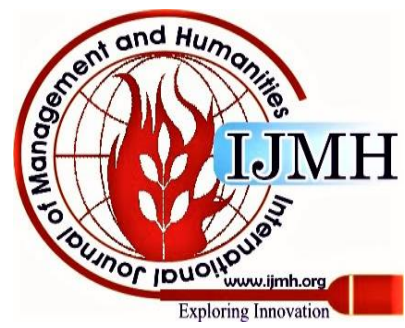




\section{CLAIMS MADE UNDER SECTION 80C TO $80 \mathrm{U}$}

\section{Combination Rank Analysis}

\begin{tabular}{|c|c|c|c|c|c|}
\hline $\begin{array}{l}\text { Ra } \\
\text { nk }\end{array}$ & Combination & $\begin{array}{c}\text { Su } \\
\text { m } \\
\text { of } \\
\text { Ra } \\
\text { nks }\end{array}$ & $\begin{array}{l}\text { Ra } \\
\text { nk }\end{array}$ & Combination & $\begin{array}{l}\text { Su } \\
\text { m } \\
\text { of } \\
\text { Ra } \\
\text { nks }\end{array}$ \\
\hline 1 & LIC - PPF & 693 & 12 & $\begin{array}{l}\text { MEDICAL - } \\
\text { PPF }\end{array}$ & 566 \\
\hline 2 & $\begin{array}{l}\text { HOUSELOAN - } \\
\text { CHILDEDU }\end{array}$ & 652 & 13 & $\begin{array}{l}\text { MEDICAL - } \\
\text { NSC }\end{array}$ & 566 \\
\hline 3 & $\begin{array}{l}\text { LIC - } \\
\text { CHILDEDU }\end{array}$ & 648 & 14 & NPS - NSC & 558 \\
\hline 4 & $\begin{array}{l}\text { HOUSELOAN - } \\
\text { PPF }\end{array}$ & 640 & 15 & $\begin{array}{l}\text { HOUSELOAN } \\
\text { - FIXEDEP }\end{array}$ & 546 \\
\hline 5 & $\begin{array}{l}\text { NPS - } \\
\text { CHILDEDU }\end{array}$ & 617 & 16 & LIC - NSC & 531 \\
\hline 6 & $\begin{array}{l}\text { NPS - } \\
\text { CHILDEDU }\end{array}$ & 617 & 17 & $\begin{array}{l}\text { FIXEDEP - } \\
\text { NSC }\end{array}$ & 529 \\
\hline 7 & $\begin{array}{l}\text { HOUSELOAN - } \\
\text { NSC }\end{array}$ & 592 & 18 & $\begin{array}{l}\text { ELSS - } \\
\text { CHILDEDU }\end{array}$ & 523 \\
\hline 8 & NPS - PPF & 588 & 19 & $\begin{array}{l}\text { DONATION - } \\
\text { CHILDEDU }\end{array}$ & 523 \\
\hline 9 & NSC - PPF & 586 & 20 & $\begin{array}{l}\text { MEDICAL - } \\
\text { CHILDEDU }\end{array}$ & 510 \\
\hline 10 & $\begin{array}{l}\text { FIXEDEP - } \\
\text { CHILDEDU }\end{array}$ & 585 & 21 & $\begin{array}{l}\text { FIXEDEP - } \\
\text { PPF }\end{array}$ & 509 \\
\hline 11 & LIC - FIXEDEP & 576 & 22 & $\begin{array}{l}\text { HOUSELOAN } \\
\text { - NPS }\end{array}$ & 459 \\
\hline
\end{tabular}

The Wilcoxon signed-rank test applied to data set to identify which best possible pair of tax saving instruments are preferred by salaried individuals claim deduction under section 80C. From the above table it finds that highest score of pair has been preferred are is LIC and PPF after that second most choosing housing loan and children education. From 80C deductions claim salaried individuals preferred combination from 10 options are as follows like LIC, Children Education Expenditure, Housing Loan, NPS, Medical Insurance and National Saving certificates. Finally form the above table these are 22 most probable combinations are using salaried individuals for tax saving and tax planning.

\section{CONCLUSION}

Form the research it can concluded that Investment pattern and factors influencing the salaried Individuals for their investment decision have been examined and found that that there is less similarity among the sample salaried Individuals in assigning the ranks to the factors influencing the salaried Individuals for their investment decision. it is understood that the highest preference has been given to Tax benefit while investing and financial planning they use to take expert advice and past experience. While examining the investment pattern LIC, PPF, NPS, Bank deposits and precious metal. Though this study it also prove that there is no single rule of prefacing investment but as per goal and objectives salaried individuals craft their decision. Accordingly they plan their tax saving strategies. It also states that Good investment together with good tax planning on the other Tax planning requires multiple perspectives and planning your taxes has an impact on your personal finance. Finally Successful Tax planning starts by understanding the rules of the tax game.

\section{REFERENCES}

1. ARORA, *MONIKA (Research Scholar, I. P. T. U. (2019). April Month Milestone. Pacific B Usiness $R$ Eview I Nternational, 136/2017-2(Monthly), NA. http://www.pbr.co.in/2017/april4.aspx

2. Arora, A. K., \& Garg, K. (2019). Awareness and Perception Regarding Tax Saving Instruments among Teachers of Higher Education. International Journal of Recent Technology and Engineering, 3 , 2277-3878. https://doi.org/10.35940/ijrte.C5847.098319

3. FCA Pratibha. (2012). A Study of Invetment Prefrances of Investors. International Journal of Application or Innovation in Engineering and Management, 1, 4847. https://ssrn.com/abstract=3032946

4. Gautam, S. L. (2013). Income Tax Planning: A Study of Tax Saving Instruments. Internaltional Journal of Management and Social Sciences Research (IJMSSR), 2(5), 83-91. https://doi.org/10.13140/RG.2.2.25046.55360

5. R Vasanthi. (2015). A Study on Tax Planning Pattern of Salaried Assessee. Research Journal of Finance and Accounting, 6(1), 170 174. www.iiste.org

6. Saravanan, K., \& MuthuLakshmi, D. K. (2017). Tax Saving Instruments of Income Tax in India: A Study on Tax Assessee in Trichy City. International Journal of Trend in Scientific Research and Development, Volume-1(Issue-5), 1259-1266. https://doi.org/10.31142/ijtsrd2469

7. Suryanarayanan, S., \& Seethalekshmy, N. (2017). A study on investment preferences amongst teachers of higher education institutions in the city of Mumbai. International Journal of Advanced Research and Development, 2(6), 446-448.

8. Yogesh P Patel, P. C., \& Charul Y Patel, P. C. (2012). A STUDY OF INVESTMENT PERSPECTIVE OF SALARIED PEOPLE (PRIVATE SECTOR). In IRJC Asia Pacific Journal of Marketing \& Management Review (Vol. 1, Issue 2). www.indianresearchjournals.com

9. KUMAR, S. (2014 ). A Study on Income Individulas Perception towards Electronic Filing. Journal of Internet Banking and Commerce, ISSN: 1204-5357.

10. Pvt., A. C. (2016). Tax Planning. India: ArthaYantra Corporation Pvt.

11. Jhamb, K. S. (2018). ANALYTICAL STUDY ON GROWTH AND PERFORMANCE OF INCOME TAX REVENUE IN INDIA International Research Journal of Commerce Arts and Science.

12. Katdare, N. G. (September 2015). INDIAN TAX STRUCTURE- AN ANALYTICAL PERSPECTIVE. Research Gate, 5.

\section{AUTHORS PROFILE}

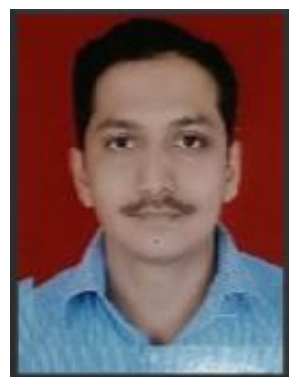

Prof.Siddhaarth R. Dhongde did his graduation (B.com) and post-graduation (M.com and MBA Finance) from Dr.Babasaheb Ambedkar Marathwada University Aurangabad Maharashtra. He has submitted his Ph.D. degree in Faculty of Management science, Dr.Babasaheb Ambedkar Marathwada University Auranagabd Maharashtra. He has been teaching Finance, Direct and Indirect Tax to students at various levels from past 12 years. He has teaching and Industry experience of more than 15 years. Currently he is associate as faculty member with Amity business School Mumbai, Amity University Maharashtra. Prof.Siddhaarth Dhongde has also conducted Management development programme for working professionals as well as working aspirants in various institutions and industry. He has addressed more than 50 seminars on finance, Direct tax and indirect tax planni

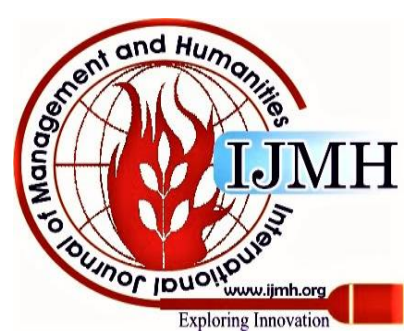


Tax Saving Investment Strategies among Salaried Individuals in Aurangabad City

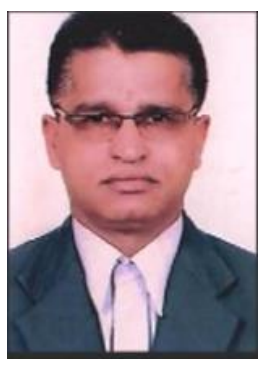

Dr. Vilas Epper is a senior professor at Dr.Babasaheb ambedkar university Auranganad. Having more than 20 years plus experience in field of teaching and training for commerce, Management students. He has guided more than 20 students for Ph.D and M. Phil in commerce as well as Management. Under his guide ship students has awarded Ph.D in Commerce and Management. He has Publish more than 30 Research paper in National and International in Journal with peer review journal. He has delivered and conducted training programmers at various level from Industry to seminars on Entrepreneurship Development, Accounts and Finance, Direct Taxation, Rural Development Management Problems \& Challenges etc. 